\title{
Osmolyte Accumulation and Sodium Compartmentation Has a Key Role in Salinity Tolerance of Pistachios Rootstocks
}

\author{
Pegah Behzadi Rad, Mahmoud Reza Roozban *, Soheil Karimi, Reza Ghahremani and Kourosh Vahdati
}

Citation: Behzadi Rad, P.; Roozban, M.R.; Karimi, S.; Ghahremani, R.; Vahdati, K. Osmolyte Accumulation and Sodium Compartmentation Has a Key Role in Salinity Tolerance of Pistachios Rootstocks. Agriculture 2021, 11, 708. https://doi.org/ 10.3390/agriculture 11080708

Academic Editor: Daniel Tan

Received: 20 May 2021

Accepted: 20 July 2021

Published: 27 July 2021

Publisher's Note: MDPI stays neutral with regard to jurisdictional claims in published maps and institutional affiliations.

Copyright: (c) 2021 by the authors. Licensee MDPI, Basel, Switzerland. This article is an open access article distributed under the terms and conditions of the Creative Commons Attribution (CC BY) license (https:// creativecommons.org/licenses/by/ $4.0 /)$.
Department of Horticulture, College of Aburaihan, University of Tehran, Tehran 3391653755, Iran; behzadi.pegah@ut.ac.ir (P.B.R.); skarimi@ut.ac.ir (S.K.); rghahremani@ut.ac.ir (R.G.); kvahdati@ut.ac.ir (K.V.) * Correspondence: mroozban@ut.ac.ir; Tel.: +98-21-360-410-89

\begin{abstract}
Physio-biochemical responses of pistachio varieties including Pistacia vera L. 'Ghazvini' (GH), P. vera 'Ghermez-Pesteh' (GP) and P. atlantica subsp. mutica (M) were assessed under salt stress to understand the common mechanisms of salt tolerance in two popular Pistacia species. In the experiment, half-sib seedlings of the varieties were subjected to high $(100 \mathrm{mM})$ and severe $(200 \mathrm{mM})$ levels of $\mathrm{NaCl}$-induced salinity for 90 days. Growth, physiological, biochemical and ionic parameters in the roots and shoots of plants were measured in the experiment. Salinity markedly declined plant growth, and increased the number of necrotic leaves (NL) and leaf abscission. In terms of physiological responses, salinity reduced the relative water content (RWC), membrane stability index (MSI) and the concentrations of photosynthetic pigments, but increased carbohydrates and proline content in the leaves. MSI of the leaves was positively correlated with the concentrations of anthocyanins and carotenoids. Salinity increased sodium content in root and shoot tissues of the plants, and decreased potassium concentration and K/Na ratio. Among the rootstocks, GH had better performance on all parameters. Despite the high concentration of $\mathrm{Na}^{+}$and low $\mathrm{K} / \mathrm{Na}$ ratio in the shoots, the lowest number of NL was found in GH under both salinity levels. The results indicated that salt tolerance in GH was most likely related to compartmentation of $\mathrm{Na}^{+}$ions. Finally, accumulation of osmolytes and sodium compartmentation were considered to be the most important mechanisms in the salt tolerance of pistachio rootstocks.
\end{abstract}

Keywords: Growth; ion distribution; mechanism; Pistacia sp.; rootstocks; salt tolerance

\section{Introduction}

Pistachio (Pistacia vera L.) is one of the most important nut crops in the world. A wide range of pistachio growing regions globally are affected by salinity. Salinization of soil is becoming a serious obstacle in agricultural lands. Low precipitation, high evaporation and irrigation with low quality water have led to the salinization of agricultural lands in recent years. Introduction of salt-tolerant plants helps to ensure global food security and achieve the projected nutritional target of feeding 9.6 billion people by 2050 [1].

Salinity affects plants in three ways: osmotic, ionic and oxidative stress [2]. Leaf thickness, leaf abscission, necrosis of plant organs, along with a decrease in internode height, leaf number and leaf area are general responses of plants to salt stress [3,4]. Increasing the $\mathrm{NaCl}$ level disrupts the equilibrium of water in plants and reduces the membrane salinity index (MSI) [5]. Most plant species accumulate osmolytes, such as proline, glycine betaine and soluble sugars in their cells to regulate osmotic pressure under salinity stress [6]. Salt stress destroys chlorophyll molecules and inhibits their synthesis [7,8]. But, salt-tolerant species are being least affected in such ways [9].

Since $\mathrm{NaCl}$ is the most soluble and widespread salt, all plants have evolved mechanisms to regulate its accumulation and to select against it in favour of other nutrients [10]. For most species, $\mathrm{Na}^{+}$appears to reach a toxic level before $\mathrm{Cl}^{-}$does, and probably for this reason most studies have been focused on $\mathrm{Na}^{+}$exclusion and the controlling of $\mathrm{Na}^{+}$ transport within the plant [11,12]. At the cellular level, high amounts of $\mathrm{Na}^{+}$and $\mathrm{Cl}^{-}$, 
which arrive in the leaves, should be largely accumulated in the vacuoles of cells. High concentrations of $\mathrm{Na}^{+}$in the soil can interfere with the absorption of $\mathrm{K}^{+}$and $\mathrm{Ca}^{2+}$. Also, low $\mathrm{K}^{+} / \mathrm{Na}^{+}$ratio and high concentrations of total salts, especially in mesophyll tissues, can inactivate enzymes and inhibit protein synthesis [13]. Therefore, a high $\mathrm{K}^{+} / \mathrm{Na}^{+}$ratio in the leaves under salt stress can be considered an indicator of salt tolerance in rootstock selection programme $[13,14]$.

Salt tolerance varies among pistachio rootstocks [15-17]. Identification of salt-tolerant rootstocks can improve growth and productivity of the plant in the salt-affected areas $[18,19]$. Mainly, plants differ greatly in their tolerance to salinity, as reflected in their different growth responses. The results of prior studies on the tolerance of $P$. vera are not in agreement, so that some suggested 'Ghazvini' as the most resistant tolerant rootstock [16,20], while others recommended 'Badami' [3,7,21] or 'Akbari' [22-25]. In previous studies on pistachio, salinity resistance, with some parameters $[3,7,20]$, has been used to select resistant rootstocks only among $P$. vera species with medium salinity in very short duration, but the mechanisms have not been identified. These inconsistencies in results are due to a lack of knowledge about the main mechanisms of salt tolerance among Pistacia species. The present research was conducted to study the physiological, biochemical and ionic responses of pistachio rootstocks (cultivar and wild genotypes together) under the most intense salinity stress to get a better understanding of common salt tolerance mechanisms in pistachio over a long term (tolerance threshold), for the first time.

\section{Materials and Methods}

Half-sib plants of three different rootstocks, namely, P. vera L. 'Ghazvini' (GH), P. vera 'Ghermez-Pesteh' (GP) and P. atlantica subsp. mutica (M) were used in the experiment. Seedlings of GH are commonly used as a salt-tolerant rootstock in Iran [17-20]. GP is a local variety, grown in the Ghazvin province of Iran, and its salt tolerance has not been studied yet. $\mathrm{M}$ is a salt-sensitive plant that is grown as a rain-fed wild species in arid and semi-arid regions of Iran.

Seeds of the pistachio rootstocks were disinfected using $2 \mathrm{~mL} \mathrm{~L}^{-1}$ Previcur ${ }^{\circledR}$ fungicide (Bayer, Germany) for $120 \mathrm{~min}$. The seeds were then washed with distilled water. The seeds were germinated in clean pieces of cloth at room temperature. They were sown in $6 \mathrm{~L}$ pots containing coco peat and perlite $(1: 2 v / v)$. The plants were irrigated three times a week with distilled water. A soilless culture was used to avoid unwanted interaction effects of the soil with salinity treatments.

Thirty-day-old seedlings were irrigated every other day with half-strength Hoagland's nutrient solution $(300 \mathrm{~mL})$ for 90 days. To prevent salt accumulation in the growing medium, pots were leached with non-saline water twice a month $\left(\mathrm{ECW}=1.06 \mathrm{dS} \mathrm{m}^{-1}\right.$; $\mathrm{pH}=7.3$ ). In time, 120-day-old plants were subjected to different concentrations of $\mathrm{NaCl}$ including $0 \mathrm{mM}\left(2.16 \mathrm{dS} \mathrm{m}^{-1}\right), 100 \mathrm{mM}\left(11.29 \mathrm{dS} \mathrm{m}^{-1}\right)$ and $200 \mathrm{mM}\left(20.42 \mathrm{dS} \mathrm{m}^{-1}\right)$, which were added to the half-strength Hoagland nutrient solution (Hoagland and Arnon, 1950), for 90 days. To avoid osmotic shock, the plants were pre-conditioned by increments of $25 \mathrm{mM} \mathrm{NaCl}$ per nutrient solution up to the desired salinity levels. The pre-conditioned seedlings were continued to their respective $\mathrm{NaCl}$ treatment. The plants were kept in a greenhouse with $40 / 50 \% \mathrm{RH}$ at $27 / 20^{\circ} \mathrm{C}$ (day/night), respectively, and a $16 \mathrm{~h}$ photoperiod. Irradiance of photosynthetic active radiation (PAR) inside of the greenhouse was $750 \mu \mathrm{m} \mathrm{s}^{-1} \mathrm{~m}^{-2}$.

At the end of the experiment, shoot height, stem diameter $(1 \mathrm{~cm}$ above the medium surface), total number of green leaves, fallen leaves and necrotic leaves (NL) of the plants were recorded. For measuring leaf area, a non-destructive method described by Karimi et al. [26] was used.

For determination of leaf relative water content (RWC), fully expanded young leaves were selected and 10 leaf discs ( $0.8 \mathrm{~cm}$ diameter) were cut using a cork borer. The discs were weighed immediately to record fresh weight (FW), immersed in distilled water in darkness for $24 \mathrm{~h}$ at $4{ }^{\circ} \mathrm{C}$ and reweighed (TW). Finally, the samples were placed in an 
oven $\left(70{ }^{\circ} \mathrm{C}\right.$ for $\left.48 \mathrm{~h}\right)$ and weighed to measure the dry weight (DW). RWC was determined according to Whetherley [27] and calculated using the following equation (Equation (1)):

$$
\operatorname{RWC}(\%)=[(\mathrm{FW}-\mathrm{DW}) /(\mathrm{TW}-\mathrm{DW})] \times 100
$$

To evaluate the membrane stability index (MSI), 20 young leaf discs were used. First, the leaf discs were washed in distilled water and put in the water bath at $40^{\circ} \mathrm{C}$ for $30 \mathrm{~min}$. Then, electrical conductivity (EC) was recorded $\left(C_{1}\right)$. After that, the samples were placed in boiling water for $10 \mathrm{~min}$ and the EC was measured $\left(C_{2}\right)$. The MSI was calculated using the following equation (Equation (2)):

$$
\operatorname{MSI}(\%)=\left[1-\left(\mathrm{C}_{1} / \mathrm{C}_{2}\right)\right] \times 100
$$

Proline content was measured according to a method described by Bates et al. [28]. Specifically, $500 \mathrm{mg}$ of oven-dried leaves were homogenized in $10 \mathrm{~mL}$ of $3 \%$ aqueous sulfosalicylic acid for $48 \mathrm{~h}$. After infiltration, ninhydrin acid reagent $(2 \mathrm{~mL})$ was added to $2 \mathrm{~mL}$ of extract and then heated in a boiling water bath for $1 \mathrm{~h}$. The chromophore was extracted by $4 \mathrm{~mL}$ toluene and its absorbance was recorded at $520 \mathrm{~nm}$ by spectrophotometry (PerkinElmer, Lambda 25, Waltham, MA, USA).

To measure glycine betaine (GB) in the leaves, powdered leaves were mixed with distilled water for $24 \mathrm{~h}$ at $25^{\circ} \mathrm{C}$ and $\mathrm{H}_{2} \mathrm{SO}_{4}$ (1:1) was added. Then, the samples were mixed with KI-I ${ }_{2}$ and incubated $\left(4^{\circ} \mathrm{C}\right.$ for $16 \mathrm{~h}$ ). Finally, the samples were centrifuged ( $15 \mathrm{~min}$ at $10,000 \mathrm{rpm}$ ) and crystals were dissolved in 1, 2-dichloroethane. After $2 \mathrm{~h}$, the absorbance was recorded at $365 \mathrm{~nm}$ by spectrophotometry (PerkinElmer, Lambda 25, Waltham, MA, USA). GB concentration was estimated using an external standard curve according to a method described by Grieve and Grattan [29].

Soluble carbohydrates (CHOs) content was assessed by adding $7 \mathrm{~mL}$ of ethanol $(70 \%)$ to $100 \mathrm{~mL}$ of leaf dried powder. The extract was centrifuged and the supernatant solution was mixed with $1 \mathrm{~mL}$ of Anthrone solution (500 mg Anthrone, $12.5 \mathrm{~mL}$ distilled water, and $250 \mathrm{~mL}$ sulphuric acid $95 \%$ ) for measuring the absorbance at $625 \mathrm{~nm}$ by spectrophotometry (PerkinElmer, Lambda 25, Waltham, MA, USA). Glucose solutions were used for the establishment of the calibration curve [30].

Anthocyanin concentration in leaves was measured according to a method described by Wagner [31]. After extraction in $10 \mathrm{~mL}$ methanol- $\mathrm{HCl}(1 \% \mathrm{HCl}, v / v)$, the absorption of the extract was measured at $550 \mathrm{~nm}$ by spectrophotometry (PerkinElmer, Lambda 25, Waltham, MA, USA). Anthocyanin concentration was determined using the extinction coefficient of $\varepsilon_{550}=33,000 \mathrm{~cm}^{2} \mathrm{~mol}^{-1}$.

To evaluate the amounts of chlorophylls (Chl) and carotenoids, $500 \mathrm{mg}$ of fresh leaf tissue was homogenized in $80 \%$ cold acetone. Then, the solution was centrifuged. The absorbance of the extracts was determined at 647,663 and $470 \mathrm{~nm}$ by spectrophotometry (PerkinElmer, Lambda 25, Waltham, MA, USA). Chlorophyll (chl. a, b and total) and carotenoid concentrations (Xanthophyll and $\beta$-Carotene) were calculated using the equations (Equation (3)) developed by Lichtenthaler [32]:

$$
\text { Chlorophyll } a_{\left(\mathrm{mg} \mathrm{mL}^{-1}\right)}=12.25 \mathrm{~A}_{663}-2.79 \mathrm{~A}_{647}
$$

Chlorophyll $b_{\left(\mathrm{mg} \mathrm{mL}^{-1}\right)}=21.51 \mathrm{~A}_{647}-510 \mathrm{~A}_{663}$

Chlorophyll Total $\left(\mathrm{mg} \mathrm{mL}^{-1}\right)=7.15 \mathrm{~A}_{663}+18.71 \mathrm{~A}_{647}$

Carotenoids $($ Xanthophyll $+\beta$-Carotene $)=\left(1000 \mathrm{~A}_{470}-1.8 \mathrm{chl} . a-85.02 \mathrm{chl} . b\right) / 198$

Sodium and potassium concentrations in the shoots and roots were measured according to a method described by Zhu et al. [33]. For this purpose, $1.0 \mathrm{~g}$ powder of the tissues was digested in nitric acid. $\mathrm{Na}^{+}$and $\mathrm{K}^{+}$ions were measured using atomic absorption spectroscopy (PerkinElmer, Waltham, MA, USA).

The experiment was conducted as a factorial, based on a completely randomized design (CRD) with two factors, salinity $(0,100$ and $200 \mathrm{mM} \mathrm{NaCl})$ and rootstock (GH, GP 
and $\mathrm{M}$ ), and three replications. Two plants per each experimental unit were used (54 plants). The analysis of variance (ANOVA) was performed using the SAS program (ver. 9.0) and the means were compared by Tukey's multiple range test $(p \leq 0.05)$.

\section{Results}

\subsection{Plant Growth and Health}

Salinity reduced growth parameters such as stem height, leaf number and leaf area. It also increased the number of necrotic leaves and leaf abscission in all plants (Table 1). Stem diameter was not influenced by the salinity treatments.

Under $200 \mathrm{mM} \mathrm{NaCl}$ treatment, the number of healthy leaves decreased in $\mathrm{GH}(34.9 \%)$, GP (59\%) and M (55\%) compared to their controls. Under intense salinity, notwithstanding the reduction of stem height in all plants, the highest subtractive trend was found in GP $(25 \%)$. Regardless of the salinity level, GH had the highest leaf area relative to the others. Also the largest reduction was found in $\mathrm{M}(81 \%)$ under salinity stress.

Leaf abscission, following senescence of the older leaves and as an index of ionic stress, rose up in all three rootstocks under salinity stress; however, the highest increase $(116.8 \%)$ was found in M rootstock, such that some of the plants lost all their leaves (Figure 1). In contrast, the highest growth parameters and the lowest impact of salinity were observed in $\mathrm{GH}$ rootstock. Salinity significantly increased the number of NL in all three rootstocks. Regardless of the $\mathrm{NaCl}$ levels, the GH had a minimum value of NL (14.9\%) and the least increasing trend $(62 \%)$ in NL (Table 1). M (93\%) and GP (73\%) showed the most increasing trend in NL, respectively (Table 1; Figure 1).

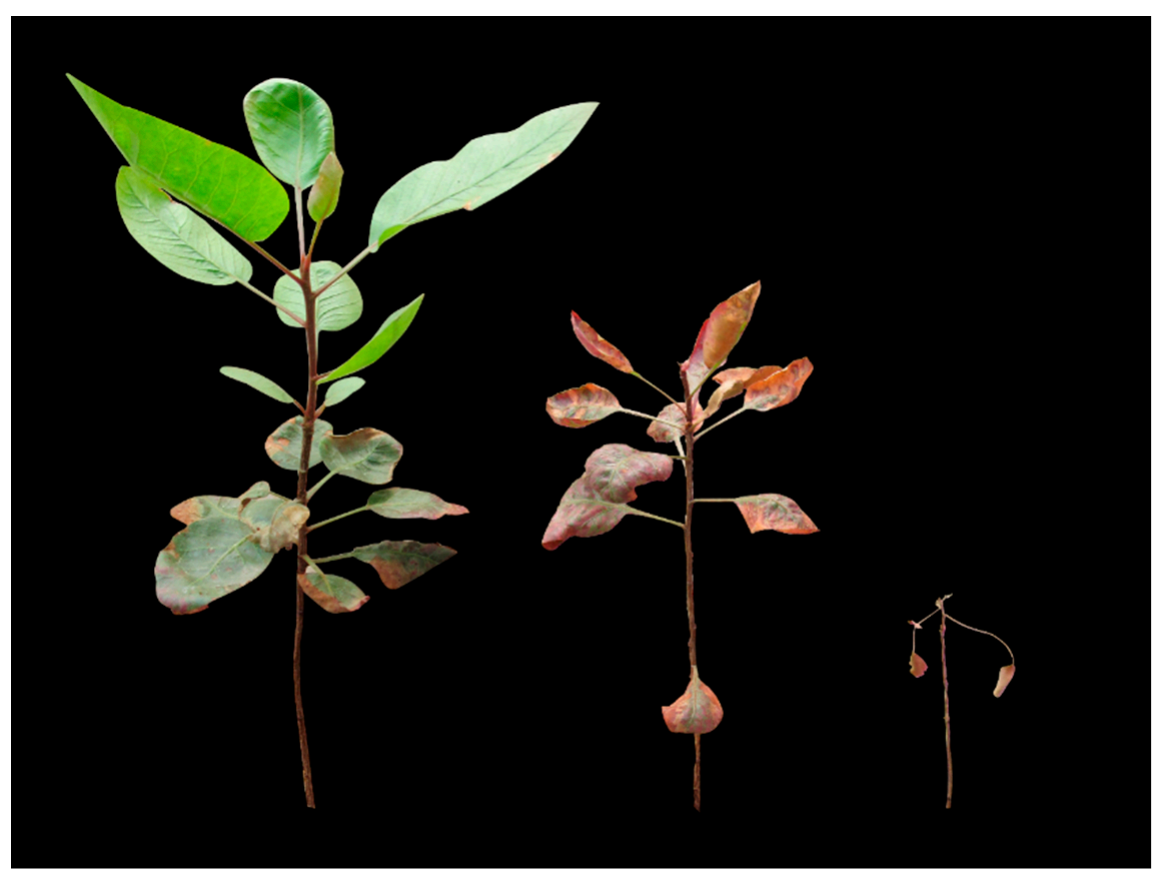

Figure 1. Appearance of the pistachio rootstocks treated with $200 \mathrm{mM} \mathrm{NaCl}$ for 90 days. 'Ghazvini' (Left), as the most tolerant rootstock, had higher growth and leaf area, followed by 'Ghermez-Pesteh' (Middle) and 'Mutica' (Right). 
Table 1. Effects of salinity on growth of three pistachio rootstocks, including GH (Ghazvini), GP (Ghermez-Pesteh) and M (P. atlantica subsp. mutica).

\begin{tabular}{|c|c|c|c|c|c|c|}
\hline Rootstock & $\begin{array}{l}\mathrm{NaCl} \\
(\mathrm{mM})\end{array}$ & $\begin{array}{l}\text { Shoot Height } \\
\text { (cm) }\end{array}$ & $\begin{array}{l}\text { Green Leaves } \\
\text { (Number) }\end{array}$ & $\begin{array}{c}\text { Necrotic Leaves } \\
(\%)\end{array}$ & $\begin{array}{l}\text { Fallen Leaves } \\
\text { (Number) }\end{array}$ & $\begin{array}{l}\text { Plant Leaf } \\
\text { Area }\left(\mathrm{cm}^{2}\right)\end{array}$ \\
\hline \multirow{3}{*}{$\mathrm{GH}$} & 0 & $28.0 \mathrm{a}$ & $47.0 \mathrm{a}$ & $10.8 \mathrm{~h}$ & $12.3 \mathrm{c}$ & $1123.4 \mathrm{a}$ \\
\hline & 100 & $25.0 \mathrm{ab}$ & $38.3 \mathrm{ab}$ & $16.5 \mathrm{f}$ & $15.3 \mathrm{bc}$ & $652.2 \mathrm{~b}$ \\
\hline & 200 & $22.3 \mathrm{abc}$ & $30.6 \mathrm{bc}$ & $17.5 \mathrm{e}$ & $20.3 \mathrm{abc}$ & $384.0 \mathrm{c}$ \\
\hline \multirow{3}{*}{ GP } & 0 & $20.6 \mathrm{bcd}$ & 18.6 de & $14.1 \mathrm{~g}$ & $26.6 \mathrm{abc}$ & $213.9 \mathrm{~d}$ \\
\hline & 100 & $17.3 \mathrm{~cd}$ & 12.6 ef & $21.9 \mathrm{~d}$ & $30.3 \mathrm{ab}$ & $142.6 \mathrm{f}$ \\
\hline & 200 & $15.3 \mathrm{~d}$ & $7.6 \mathrm{f}$ & $24.5 \mathrm{c}$ & $36.6 \mathrm{a}$ & $76.0 \mathrm{~g}$ \\
\hline \multirow{3}{*}{ M } & 0 & $16.3 \mathrm{~cd}$ & $32.0 \mathrm{bc}$ & $14.8 \mathrm{~g}$ & $16.6 \mathrm{bc}$ & 396.2 c \\
\hline & 100 & $15.0 \mathrm{~d}$ & $24.3 \mathrm{de}$ & $26.8 \mathrm{~b}$ & $24.3 \mathrm{abc}$ & $189.2 \mathrm{e}$ \\
\hline & 200 & $14.6 \mathrm{~d}$ & 14.3 ef & $28.6 \mathrm{a}$ & $36.0 \mathrm{a}$ & $72.5 \mathrm{~g}$ \\
\hline
\end{tabular}

Different letters within each column show significant differences according to Tukey's multiple-range test $(p \leq 0.05)$.

\subsection{Physiological Parameters}

Salinity stress significantly affected leaf RWC. Relative water content of the leaves decreased in all the rootstocks in line with increasing salinity level, and the lowest RWC was found under $200 \mathrm{mM} \mathrm{NaCl}$ treatment. The lowest RWC was observed in GP under $200 \mathrm{mM} \mathrm{NaCl}$. Also, the sharpest trend of decline in RWC (8.5\%) was observed in GP, as compared with its control (Figure 2A).
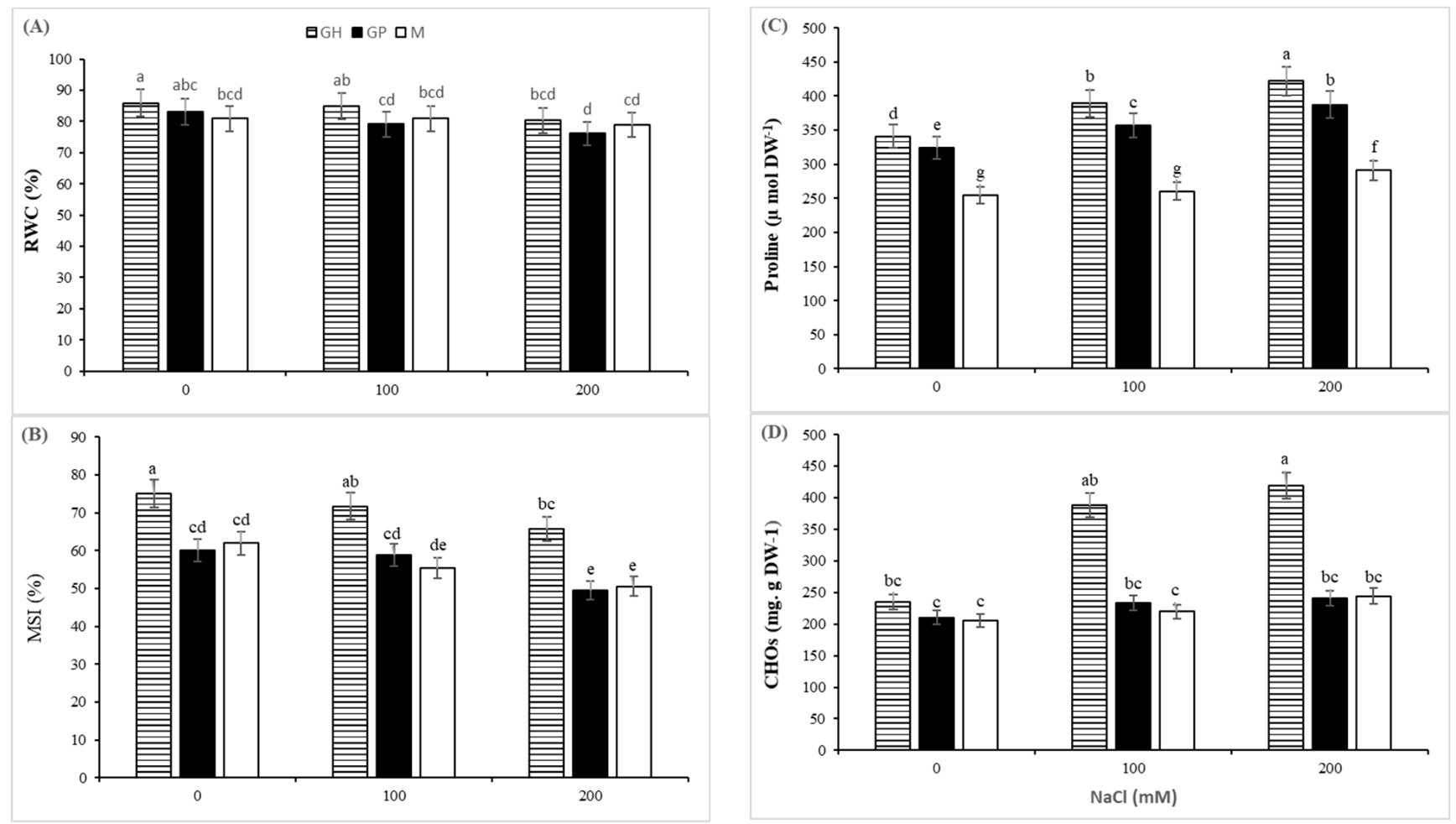

Figure 2. The effect of controlled salt treatment on RWC (A), MSI (B), and proline content (C) and CHOs (D)) of three pistachio rootstocks including GH (Ghazvini), GP (Ghermez-Pesteh) and M (P. atlantica subsp. mutica). Bars with different letters shows significant difference according to Tukey's multiple range test $(p<0.05)$.

The membrane stability index of the leaves, as an indicator of resistance against membrane peroxidation, was significantly affected by rootstock, salinity and their interaction. Regardless of $\mathrm{NaCl}$ levels, $\mathrm{GH}$ had the largest value of MSI (70.8\%). A significant decrease in MSI was observed in 100 and $200 \mathrm{mM} \mathrm{NaCl}$ treatments in all three rootstocks (Figure 2B). The MSI declined by 18.3, 17.3 and $12.4 \%$ in M, GP and GH, respectively. Positive correla- 
tions were observed between MSI, RWC, and carotenoids and anthocyanin contents in the leaves (Figure 3).
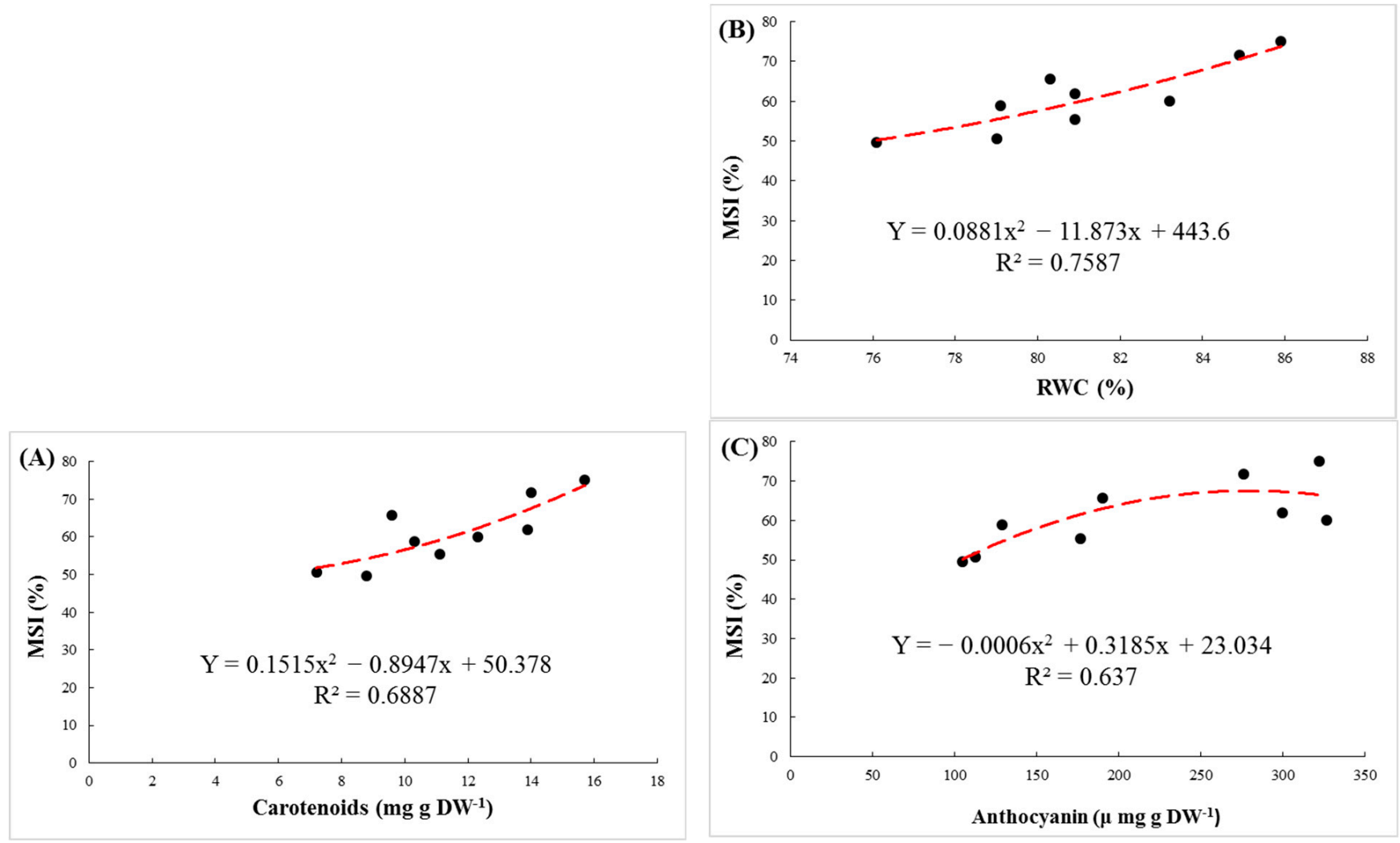

Figure 3. The regression between membrane stability index (MSI) and carotenoids (A), relative water content (RWC) (B) and anthocyanin $(\mathbf{C})$ in leaves of pistachio rootstocks under salinity stress.

\subsection{Biochemical Parameters}

Leaf proline concentration increased when $\mathrm{NaCl}$ concentration increased in the nutrient solution (Figure 2D). The highest leaf proline content was found in GH, which is considered the most salt-tolerant rootstock in this study. The highest concentration of proline in this rootstock was $422 \mu \mathrm{mol} \mathrm{g} \mathrm{DM}{ }^{-1}$ at $200 \mathrm{mM} \mathrm{NaCl}$, having a $24 \%$ increase compared to the respective control $\left(340.6 \mu \mathrm{mol} \mathrm{g} \mathrm{DM}^{-1}\right)$. Glycine betaine content was not significantly affected by the salinity treatments. In all three rootstocks, soluble $\mathrm{CHOs}$ were increased by raising the salinity level. The highest concentration of soluble $\mathrm{CHOs}$ was in leaves of GH under $200 \mathrm{mM} \mathrm{NaCl}$ stress (Figure 2C).

Excepting for chlorophyll $b$, the rootstock, salinity and interaction between them strongly affected concentrations of chlorophyll a, chlorophyll a:b ratio and total chlorophylls, carotenoids and anthocyanin in the leaves. As the salinity levels rose, chlorophyll content ( $a, a: b$, total) decreased, compared with the control in all three rootstocks (Table 2). In general, the highest levels of chlorophyll and the lowest decrement were found in $\mathrm{GH}$. Salinity stress significantly decreased the amount of anthocyanin in the plants. In GP, this decrease (compared with control) was more evident (69\%). Also, the carotenoids content of plants decreased significantly under salinity stress. The most significant effect of salinity on carotenoids was found in $\mathrm{M}(48 \%)$. Under salinity stress, the concentration of anthocyanin was decreased significantly in the studied plants. This reduction in GP was more noticeable $(69 \%)$.

Regardless of salinity level, the highest amount of photosynthetic pigments, proline and $\mathrm{CHOs}$ was found in the $\mathrm{GH}$ rootstock, which demonstrates its salt tolerance. 
Table 2. Effects of salinity treatment on photosynthetic pigments (chlorophyll a, a/b, total), carotenoids and anthocyanin of three pistachio rootstocks including GH (Ghazvini), GP (Ghermez-Pesteh) and M (P. atlantica subsp. mutica).

\begin{tabular}{|c|c|c|c|c|c|c|}
\hline Rootstock & $\begin{array}{l}\mathrm{NaCl} \\
(\mathrm{mM})\end{array}$ & $\begin{array}{c}\text { Chl. a } \\
\left(\mathrm{mg} \mathrm{g} \mathrm{FW}^{-1}\right)\end{array}$ & Chl. a/b Ratio & $\begin{array}{c}\text { Total Chl. } \\
\left(\mathrm{mg} \mathrm{g} \mathrm{FW}^{-1}\right)\end{array}$ & $\begin{array}{l}\text { Carotenoids } \\
\left(\mathrm{mg} \mathrm{g} \mathrm{FW}^{-1}\right)\end{array}$ & $\begin{array}{c}\text { Anthocyanin } \\
\left(\mu \mathrm{mol} \mathrm{g} \mathrm{FW}^{-1}\right)\end{array}$ \\
\hline \multirow{4}{*}{$\mathrm{GH}$} & 0 & $31.4 \mathrm{a}$ & $22.8 \mathrm{ab}$ & $33.3 \mathrm{a}$ & $15.7 \mathrm{a}$ & $322 \mathrm{a}$ \\
\hline & 100 & $24.2 \mathrm{~b}$ & $19.4 \mathrm{abc}$ & $30.5 \mathrm{ab}$ & $14.1 \mathrm{ab}$ & $276 \mathrm{c}$ \\
\hline & 200 & 13.7 ef & $15.6 \mathrm{~cd}$ & $28.6 \mathrm{ab}$ & $9.6 \mathrm{ce}$ & $189.6 \mathrm{~d}$ \\
\hline & 0 & $24.8 \mathrm{~b}$ & $24.6 \mathrm{a}$ & $22 b c$ & $13.3 \mathrm{abc}$ & $327.8 \mathrm{a}$ \\
\hline \multirow[t]{3}{*}{ GP } & 100 & $22 \mathrm{bc}$ & $17.5 \mathrm{bcd}$ & $16.7 \mathrm{~cd}$ & 10.3 bcde & $129 \mathrm{f}$ \\
\hline & 200 & $18.1 \mathrm{~cd}$ & $9.4 \mathrm{e}$ & $10.3 \mathrm{~d}$ & $8.8 \mathrm{de}$ & $105.3 \mathrm{~g}$ \\
\hline & 0 & $22.2 \mathrm{bc}$ & $21.4 \mathrm{abc}$ & $29.8 \mathrm{ab}$ & $13.9 \mathrm{ab}$ & $300 \mathrm{~b}$ \\
\hline \multirow[t]{2}{*}{ M } & 100 & $17 \mathrm{de}$ & $17.5 \mathrm{bc}$ & $27.8 \mathrm{ab}$ & $12.1 \mathrm{abcd}$ & $177 \mathrm{e}$ \\
\hline & 200 & $11.2 \mathrm{f}$ & $12 \mathrm{de}$ & $24.4 \mathrm{ab}$ & $7.2 \mathrm{e}$ & $113 \mathrm{~g}$ \\
\hline
\end{tabular}

Different letters within each column show significant differences according to Tukey's multiple-range test $(p \leq 0.05)$.

\subsection{Ions Distribution}

Distribution of $\mathrm{Na}^{+}$and $\mathrm{K}^{+}$between shoots and roots was considerably affected by salt stress. $\mathrm{NaCl}$ treatments significantly increased $\mathrm{Na}^{+}$accumulation in all shoot and roots of the plants. Under severe salinity, this increment in the shoots of GP was more pronounced than that in the shoots of GH (Figure 4A,B). Moreover, under $200 \mathrm{mM} \mathrm{NaCl}$, GH had the lowest sodium content in its roots compared with the other rootstocks.
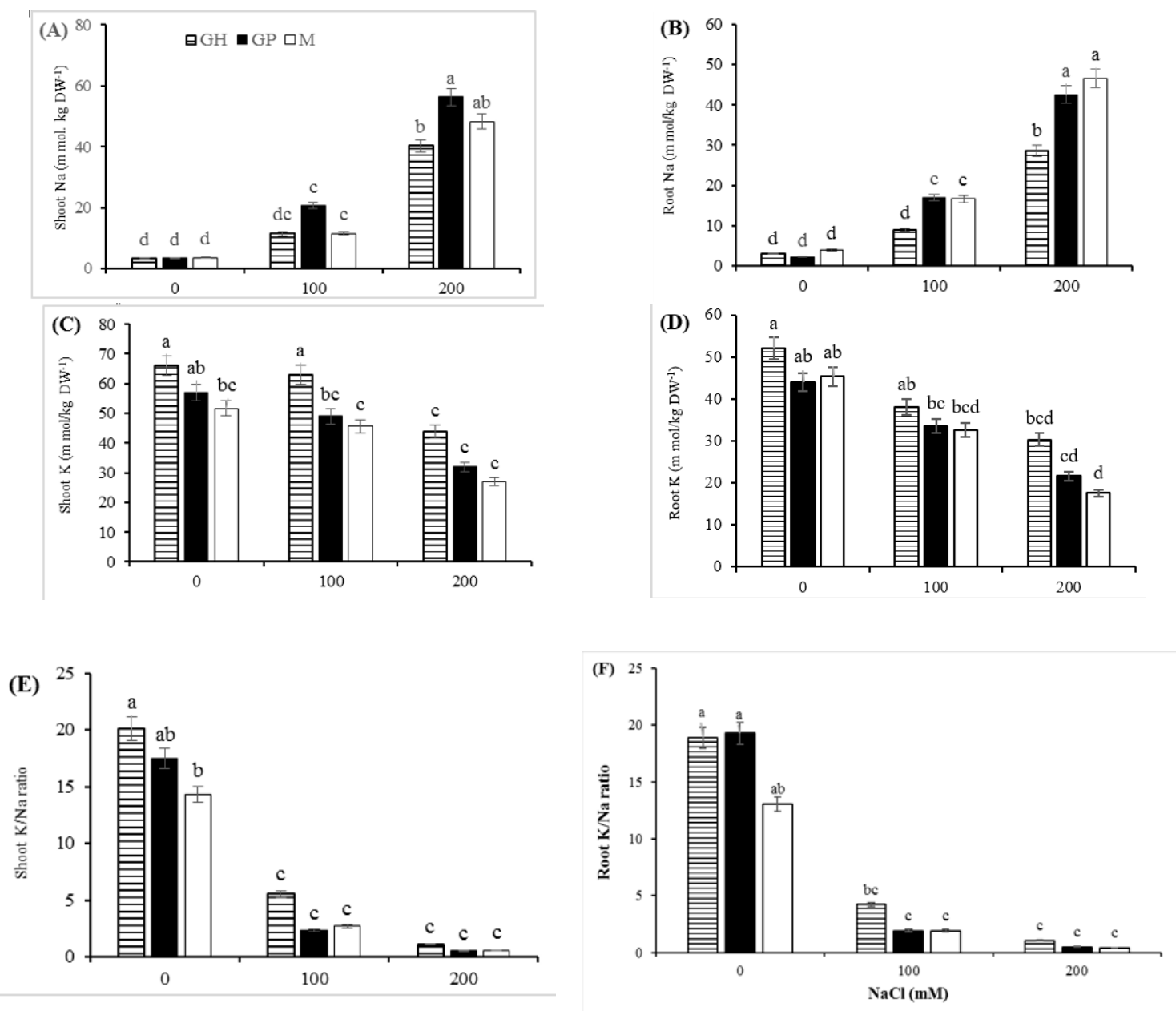

Figure 4. Effect of salinity on $\mathrm{Na}^{+}(\mathbf{A}, \mathbf{B})$ and $\mathrm{K}^{+}$distribution $(\mathbf{C}, \mathbf{D})$ and $\mathrm{K}^{+} / \mathrm{Na}^{+}$ratio $(\mathbf{E}, \mathbf{F})$ in shoot and root organs of three pistachio rootstocks including GH (Ghazvini), GP (Ghermez-Pesteh) and M (P. atlantica subsp. mutica). Means followed by the same letter are not significantly different according to Tukey's multiple range test $(p<0.05)$. 
The salinity stress treatments sharply reduced the $\mathrm{K}^{+}$content in shoots and roots of the rootstocks. A dramatic decrease in $\mathrm{K}^{+} / \mathrm{Na}^{+}$ratio was observed in the shoots and roots by increasing the salinity level. The $\mathrm{K}^{+}$content and $\mathrm{K}^{+} / \mathrm{Na}^{+}$ratio of the most salttolerant rootstock $(\mathrm{GH})$ was always higher than that in the other rootstocks, regardless of the intensity of salt stress (Figure $4 \mathrm{C}-\mathrm{F}$ ). There was a positive correlation between the $\mathrm{K}^{+}$ content of shoots and growth parameters such as stem height, leaf number and plant leaf area (Figure 5).
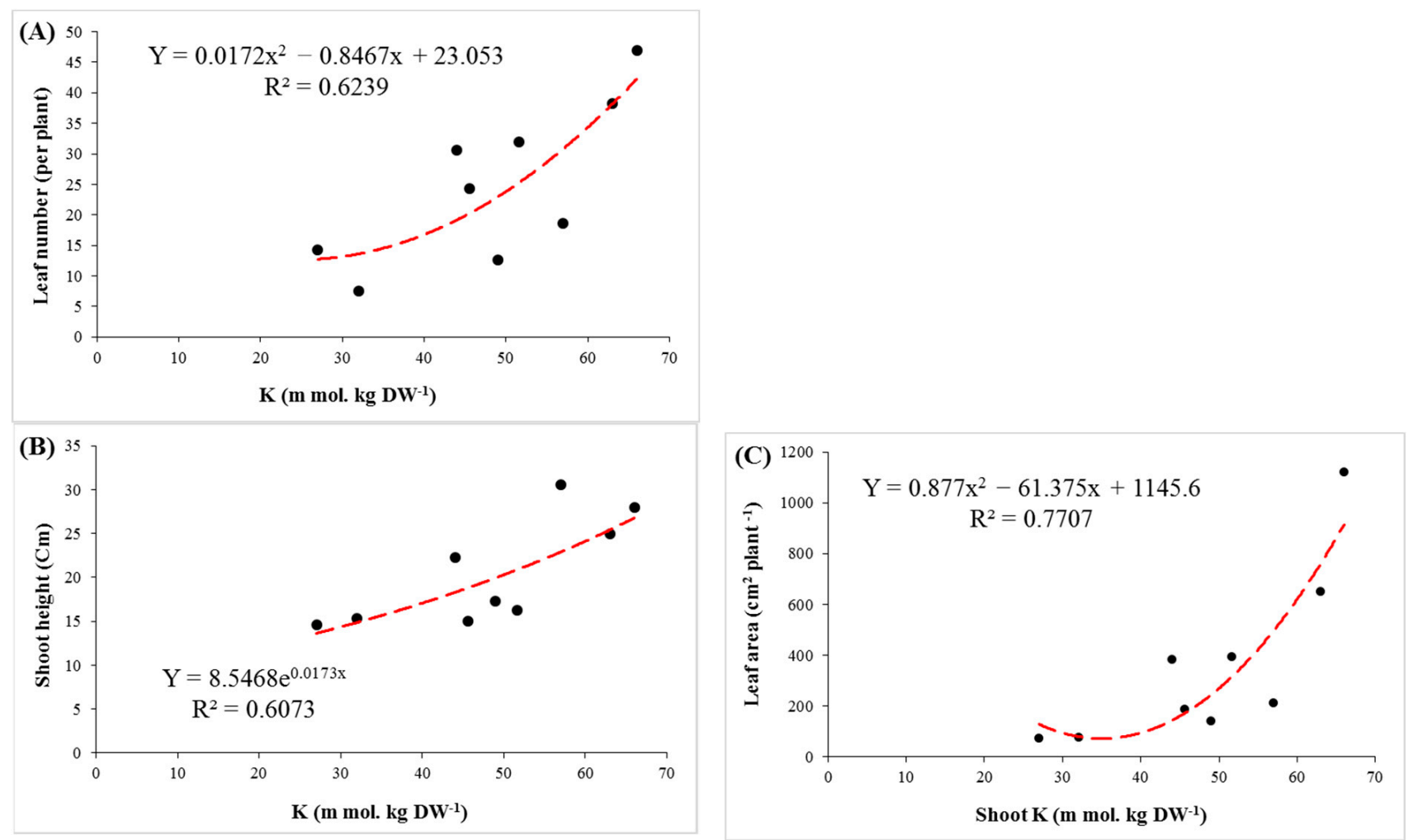

Figure 5. The regression of $\mathrm{K}^{+}$concentration in shoots with leaf number (A), shoot height (B) and leaf area (C) in three pistachio rootstocks after 90 days of salinity stress.

\section{Discussion}

Plants differences in salinity tolerance are reflected in their different growth under salt stress. Previous studies have demonstrated that salinity-tolerant plants have higher growth rates under salinity stress $[10,34,35]$. In the present study, GH, as a salt-tolerant rootstock, had the highest values of growth parameters under salinity. Also, minimum injuries of salinity stress, including number of necrotic leaves and abscission following accumulation of $\mathrm{Na}^{+}$, were found in GH. In addition to the toxic effects, the accumulation of $\mathrm{Na}^{+}$ions in leaves is accompanied by an increase in oxidative stress. Oxidative stress causes leaf damage and the breakdown of pigments, including chlorophylls, carotenoids and anthocyanins $[7,36]$.

In higher plants, the fastest effect of salinity is a reduction of RWC due to osmotic stress and cellular dehydration. In species that are susceptible to salt stress, the RWC is reduced more [37]. In the present study, despite the relative decrease of RWC in all genotypes, it can be seen that RWC was similar at $200 \mathrm{mM} \mathrm{NaCl}$, which means that all three rootstocks were successful in using cell water retention mechanisms (Figure 2A). A high level of MSI is considered to be an important indicator of tolerance to abiotic stress in plants [38]. Other researchers also confirmed that the MSI of plants declines under $\mathrm{NaCl}$ treatment [39,40]. In our study, the highest MSI level was found in the GH rootstock, considered the most salt-tolerant rootstock in this experiment. The positive correlation 
found between RWC and MSI indicated that preserving plant water content is a crucial factor in improving MSI under salinity stress.

Osmotic adjustment is an adaptive mechanism for maintenance of turgor pressure under drought and/or salinity stress conditions. The accumulation of osmolytes, such as proline and carbohydrates, in cells help plants regulate cell osmotic pressure under salinity stress. Proline plays some roles in $\mathrm{pH}$ adjustment in the cytosol protecting cell membranes and proteins, thereby bringing reactive oxygen species into a normal range. Proline is also known as a source of carbon and nitrogen for plant recovery after stress. In addition to their role in osmoregulation, soluble sugars act as a source of energy and protect the photosynthetic system by $\mathrm{Na}^{+}$sequencing compound. In this study, salinity stress enhanced proline and $\mathrm{CHOs}$ accumulation in the studied rootstocks, which was in agreement with the results of previous studies $[1,3,6,16,17,41-43]$. Therefore, high levels of proline and $\mathrm{CHOs}$ in $\mathrm{GH}$ rootstock may explain its higher tolerance to salinity compared with the other rootstocks.

Changes in concentrations of pigments under salt stress can be used as a biochemical marker for selecting salinity-tolerant rootstocks [44,45]. In the present study, a significant decrease was observed in the amount of chlorophylls $(\mathrm{a}, \mathrm{a} / \mathrm{b}$ and total) with increasing salinity. This reduction can be attributed to several factors, such as the reduction in synthesis of chlorophylls by inhibiting the enzyme $\delta$-aminolevulinic acid dehydratase and protochlorophyllide reductase, the demolition of pigment structure, perturbation in the pigment-protein complex and by deficiencies in $\mathrm{Mg}^{2+}, \mathrm{Fe}^{2+}, \mathrm{Zn}^{2+}$ and $\mathrm{Mn}^{2+}$ that are essential for the synthesis of chlorophyll $[7,46]$. Carotenoids play a role in membrane stabilization, cell growth stimulation and restriction of oxidative damage in chloroplasts under salinity stress $[47,48]$. In our study, salinity treatments significantly decreased carotenoid content in all three rootstocks. Our results are in agreement with those previously reported on the Pistacia species [17]. GH, as the most salt-tolerant rootstock, showed the highest amount of photosynthetic pigments and carotenoids under stress conditions. Parida and Das [36] reported that the chlorophyll and carotenoid content of leaves tends to decrease by higher levels of salinity. A deficiency in carotenoids can encourage ABA and IAA biosynthesis, thereby affecting drought tolerance in plants under salt stress. Positive correlations were observed among carotenoids contents, RWC and the MSI, which suggest that carotenoids content under salinity stress is an important indicator for stress tolerance in pistachio (Figures 5 and 6 ).

Anthocyanin accumulation was found under salinity stress. Besides acting as an antioxidant, anthocyanin acted as an osmo-regulator. Regression between anthocyanin and RWC shows that anthocyanins, as an osmolyte, prevents water loss in cells (Figure 6). The toxicity of $\mathrm{Na}^{+}$and $\mathrm{Cl}^{-}$ions can inhibit the synthesis and accumulation of anthocyanin in cells $[8,49,50]$. Therefore, accumulation of anthocyanin is related to salt tolerance of plants [9]. In our experiment, also the largest concentration of anthocyanin and the minimal reduction rate were observed in $\mathrm{GH}$.

Under saline conditions, accumulation of $\mathrm{Na}^{+}$in shoots and roots was observed in the studied rootstocks. The $\mathrm{Na}^{+}$accumulation in shoots was higher than the roots in all three rootstocks, which was consistent with the results of previous studies $[44,51,52]$. Accumulation of sodium in plant tissues in salt-sensitive species is greater than in tolerant ones. Some rootstocks, by mechanisms such as ion compartmentation in the vacuole (intracellular compartmentalization) and $\mathrm{Na}^{+}$exclusion from cytosol, reduce the damaging effects of sodium in cells [53-55]. By increasing the level of salinity, the $\mathrm{K}^{+}$content decreased significantly in both shoots and roots of the rootstocks. Maintaining a proportionate level of $\mathrm{K}^{+}$is necessary for plant tolerance under saline environments. Potassium plays a crucial role in physiological activities, such as stomatal movements, osmotic adjustment, cell growth and metabolism, protein synthesis and ROS mitigation, thereby maintaining cellular adjustment and turgor. This also leads to a stronger chlorophyll structure and more co-factors for enzyme production and membrane integrity [14,56,57]. Owing to the vital role of potassium in cellular metabolism, high levels of $\mathrm{K}^{+}$content can be considered a 
salt-tolerant factor in plants [58-61]. The relation between $\mathrm{K}^{+}$content and leaf number indicated that high concentrations of $\mathrm{K}^{+}$can be a stimulus for an increase in the number of leaves (Figure 5A). On the other hand, significant positive correlations were found between $\mathrm{K}^{+}$content with shoot height, and leaf area per plant (Figure 5B,C). This demonstrates that the $\mathrm{K}^{+}$content is of crucial importance for maintaining growth parameters under salinity stress.
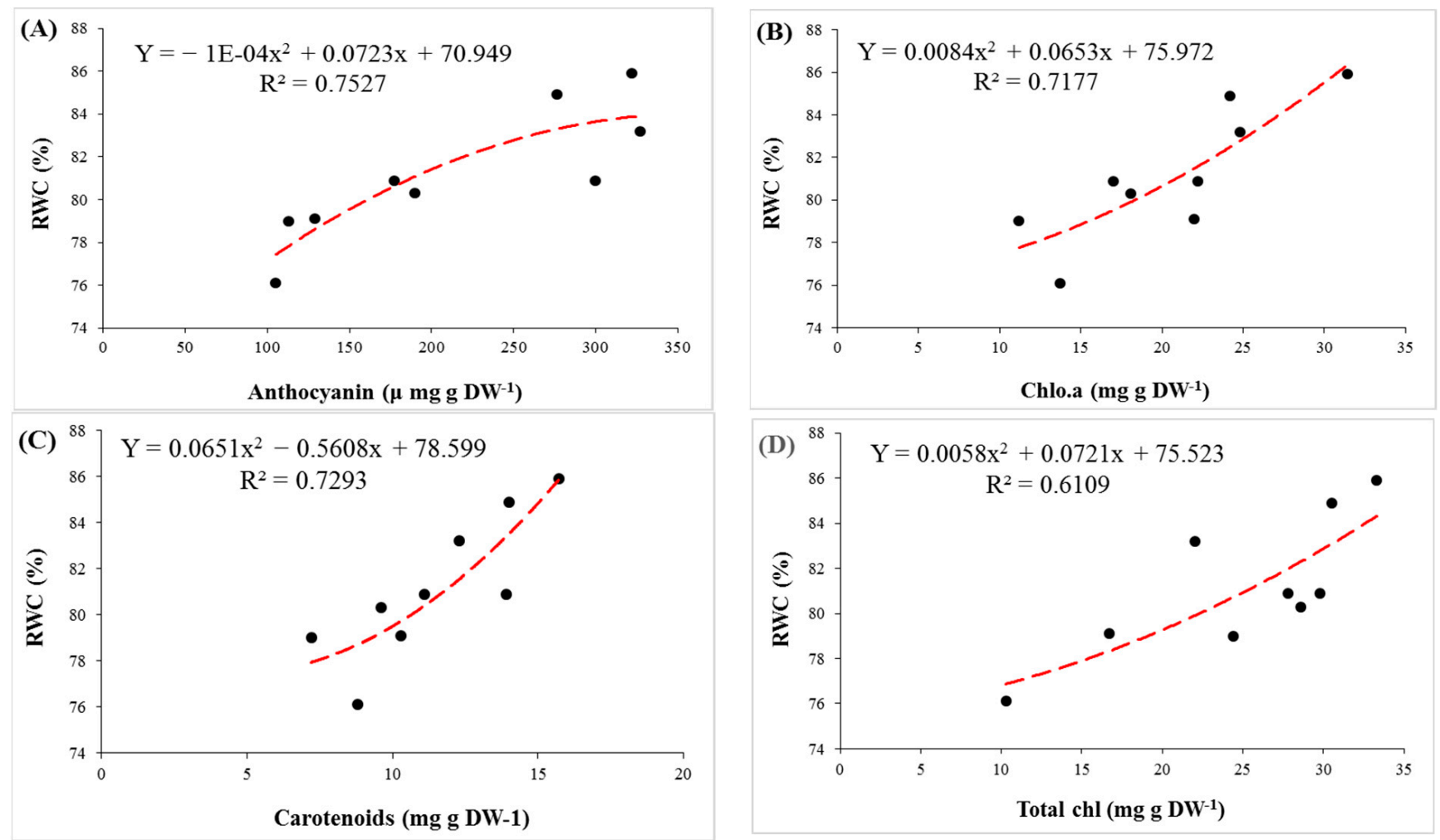

Figure 6. The regression between concentrations of plant pigments (anthocyanin (A), chlorophyll a (B), carotenoids (C) and total chlorophyll (D)) and relative water content (RWC) in leaves of pistachio rootstocks under salinity stress.

\section{Conclusions}

The interactive effects of salt stress and rootstocks in pistachio demonstrated that the response of plants to $\mathrm{NaCl}$-induced salinity mostly depends on genotype, not species. Salinity restricted the studied plants' growth and increased the number of necrotic leaves and leaf abscission. The highest amount of growth parameters and the lowest number of necrotic leaves (NL) were found in 'Ghazvini' (GH), which is considered a salt-tolerant rootstock. The highest values of leaf pigments, proline and soluble carbohydrates concentrations were found in $\mathrm{GH}$ under salinity stress. $\mathrm{GH}$ rootstock showed the least $\mathrm{Na}^{+}$ accumulation, the highest $\mathrm{K}^{+}$content and steepest $\mathrm{K}^{+} / \mathrm{Na}^{+}$ratio during the stress period.

Finally we confirmed that a tolerant genotype of pistachio, which maintains cell osmotic pressure by using osmoprotectants, such as soluble sugars and proline, and can somewhat maintain its growth rate under osmotic stress induced by salinity. Meanwhile, in spite of high concentrations of $\mathrm{Na}^{+}$and low $\mathrm{K} / \mathrm{Na}$ ratio in shoots, the lowest number of NL was found in $\mathrm{GH}$ under both salinity levels. According to our findings, tolerant genotypes most likely maintain low cytosolic sodium in their shoots using compartmentation. At the same time, maintaining the stability of the membrane at high salinity in tolerant genotypes indicates that their tolerance to oxidative stress is related to photoprotective mechanisms of pigments, such as anthocyanins and particularly carotenoids. Our results revealed that salt tolerance in pistachio is related to maintaining cell osmotic pressure and the compartmentation of toxic ions. 
Author Contributions: M.R.R. led and coordinated the project. M.R.R. and S.K. designed the experiment. P.B.R., M.R.R., S.K., R.G. and K.V. performed the experiment, analyzed the obtained data and wrote manuscript. All authors commented on the results and the manuscript. All authors have read and agreed to the published version of the manuscript.

Funding: This research received no external funding.

Institutional Review Board Statement: Not applicable.

Informed Consent Statement: Not applicable.

Data Availability Statement: The data presented in this study are available on request from the corresponding author.

Acknowledgments: The authors appreciate Iran National Science Foundation (INSF) and the University of Tehran for their supports. Mohammad Sadat Hosseini is also acknowledged for his scientific collaborations.

Conflicts of Interest: No potential conflict of interest was reported by the authors.

$\begin{array}{ll}\text { Abbreviations } \\ \text { Chl } & \text { Chlorophyll } \\ \text { CHOs } & \text { carbohydrates } \\ \text { MSI } & \text { membrane stability index } \\ \text { RWC } & \text { relative water content } \\ \text { NL } & \text { necrotic leaves } \\ \text { GP } & \text { Pistacia vera 'Ghermez Pesteh' } \\ \text { GH } & \text { P. vera 'Ghazvini' } \\ \text { M } & \text { P. atlantica subsp. mutica }\end{array}$

\section{References}

1. Singh, A. Soil salinization and waterlogging: A threat to environment and agricultural sustainability. Ecol. Indic. 2015, 57, 128-130. [CrossRef]

2. Volkov, V.; Beilby, M.J. Salinity Tolerance in Plants: Mechanisms and Regulation of Ion Transport. Front. Plant Sci. 2017, 8, 1795.

3. Rahneshan, Z.; Nasibi, F.; Moghadam, A.A. Effects of salinity stress on some growth, physiological, biochemical parameters and nutrients in two pistachio (Pistacia vera L.) rootstocks. J. Plant Interact. 2018, 13, 73-82. [CrossRef]

4. Vahdati, K.; Lotfi, N. Abiotic Stress Tolerance in Plants with Emphasizing on Drought and Salinity Stresses in Walnut. In Abiotic Stress-Plant Responses and Applications in Agriculture; Vahdati, K., Leslie, C., Eds.; InTech: Rijeka, Croatia, 2013 ; pp. $307-365$.

5. Acosta-Motos, J.R.; Ortuño, M.F.; Bernal-Vicente, A.; Diaz-Vivancos, P.; Sanchez-Blanco, M.J.; Hernandez, J.A. Plant responses to salt stress: Adaptive mechanisms. Agronomy 2017, 7, 18. [CrossRef]

6. Karimi, S.; Karami, H.; Mokhtassi-Bidgoli, A.; Tavallali, V.; Vahdati, K. Inducing drought tolerance in greenhouse grown Juglans regia by imposing controlled salt stress: The role of osmotic adjustment. Sci. Hortic. 2018, 239, 181-192. [CrossRef]

7. Akbari, M.; Mahna, N.; Ramesh, K.; Bandehagh, A.; Mazzuca, S. Ion homeostasis, osmoregulation, and physiological changes in the roots and leaves of pistachio rootstocks in response to salinity. Protoplasma 2018, 255, 1349-1362. [CrossRef]

8. Garriga, M.; Retamales, J.B.; Romero-Bravo, S.; Caligari, P.D.; Lobos, G.A. Chlorophyll, anthocyanin, and gas exchange changes assessed by spectroradiometry in Fragaria chiloensis under salt stress. J. Integr. Plant Biol. 2014, 56, 505-515. [CrossRef]

9. Nakabayashi, R.; Yonekura-Sakakibara, K.; Urano, K.; Suzuki, M.; Yamada, Y.; Nishizawa, T.; Michael, A.J. Enhancement of oxidative and drought tolerance in Arabidopsis by overaccumulation of antioxidant flavonoids. Plant J. 2014, 77, 367-379. [CrossRef] [PubMed]

10. Munns, R.; Tester, M. Mechanisms of salinity tolerance. Ann. Rev. Plant Biol. 2008, 59, 651-681. [CrossRef]

11. Genc, Y.; Oldach, K.; Taylor, J.; Lyons, G.H. Uncoupling of sodium and chloride to assist breeding for salinity tolerance in crops New Phytol. 2016, 210, 145-156. [CrossRef]

12. Taiz, L.; Zeiger, E. Plant Physiology, 5th ed.; Sinauer Associates: Sunderland, MA, USA, 2010.

13. Chen, Z.; Pottosin, I.; Cuin, T.A.; Fuglsang, A.T.; Tester, M.; Jha, D.; Zepeda-Jazo, I.; Zhou, M.; Palmgren, M.G.; Newman, I.A.; et al. Root plasma membrane transporters controlling $\mathrm{K}^{+} / \mathrm{Na}^{+}$homeostasis in salt-stressed barley. Plant Physiol. 2007, 145, 1714-1725. [CrossRef]

14. Shabala, S.; Cuin, T.A. Potassium transport and plant salt tolerance. Physiol. Plant. 2008, 133, 651-669. [CrossRef]

15. Hajiboland, R.; Norouzi, F.; Poschenrieder, C. Growth, physiological, biochemical and ionic responses of pistachio seedlings to mild and high salinity. Trees 2014, 28, 1065-1078. [CrossRef] 
16. Hokmabadi, H.; Arzani, K.; Grierson, P.F. Growth, chemical composition, and carbon isotope discrimination of pistachio (Pistacia vera L.) rootstock seedlings in response to salinity. Aust. J. Agric. Res. 2005, 56, 135-144. [CrossRef]

17. Karimi, S.; Rahemi, M.; Maftoun, M.; Tavallali, V. Effects of long-term salinity on growth and performance of two pistachio (Pistacia L.) rootstocks. Aust. J. Basic Appl. Sci. 2009, 3, 1630-1639.

18. Nadernejad, N.; Ahmadimoghadam, A.; Hossyinifard, J.; Poorseyedi, S. Effect of different rootstocks on PAL activity and phenolic compounds in flowers, leaves, hulls and kernels of three pistachio (Pistacia vera L.) cultivars. Trees 2013, 27, 1681-1689. [CrossRef]

19. Zeng, L.; Tu, X.L.; Dai, H.; Han, F.M.; Lu, B.S.; Wang, M.S.; Nanaei, H.A.; Tajabadipour, A.; Mansouri, M.; Li, X.L.; et al. Whole genomes and transcriptomes reveal adaptation and domestication of pistachio. Genome Biol. 2019, 20, 79. [CrossRef]

20. Momenpour, A.; Imani, A. Evaluation of salinity tolerance in fourteen selected pistachio (Pistacia vera L.) cultivars. Adv. Hortic. Sci. 2018, 32, 249-264.

21. Jamshidi, K.G.; Amirmahani, F.; Salehi, F. Assessment of changes in physiological and biochemical traits in four pistachio rootstocks under drought, salinity and drought+ salinity stresses. Physiol. Plant. 2020, 168, 973-989. [CrossRef]

22. Akbari, M.; Katam, R.; Husain, R.; Farajpour, M.; Mazzuca, S.; Mahna, N. Sodium Chloride Induced Stress Responses of Antioxidative Activities in Leaves and Roots of Pistachio Rootstock. Biomolecules 2020, 10, 189. [CrossRef]

23. Mirfattahi, Z.; Karimi, S.; Roozban, M.R. Salinity induced changes in water relations, oxidative damage and morpho-physiological adaptations of pistachio genotypes in soilless culture. Acta Agric. Slov. 2017, 109, 291-302. [CrossRef]

24. Raoufi, A.; Rahemi, M.; Salehi, H.; Javanshah, A. Selecting high-performance rootstocks for pistachio cultivars under salinity stress based on their morpho-physiological characteristics. Int. J. Fruit Sci. 2019, 20 (Suppl. 2), S29-S47. [CrossRef]

25. Raoufi, A.; Rahemi, M.; Salehi, H.; Pessarakli, M. Pistacia vera L. genotypes; a potential rival for UCB-1 rootstock for cultivating under salt stress conditions. Biocatal. Agric. Biotechnol. 2020, 25, 101515. [CrossRef]

26. Karimi, S.; Tavallali, V.; Rahemi, M.; Rostami, A.A.; Vaezpour, M. Estimation of leaf growth on the basis of measurements of leaf hights and widths, choosing pistachio seedlings as model. Aust. J. Basic Appl. Sci. 2009, 3, 1070-1075.

27. Whetherley, P.E. Studies in the water relations of cotton plants. I. The field measurement of water deficit in leaves. New Phytol. 1950, 49, 81-87. [CrossRef]

28. Bates, L.S.; Waldren, R.P.; Teare, I.D. Rapid determination of free proline for water-stress studies. Plant Soil 1973, 39, 205-207. [CrossRef]

29. Grieve, C.M.; Grattan, S.R. Rapid assay for determination of water soluble quaternary ammonium compounds. Plant Soil 1983, 70, 303-307. [CrossRef]

30. Vandoorne, B.; Mathieu, A.S.; Van den Ende, W.; Vergauwen, R.; Périlleux, C.; Javaux, M.; Lutts, S. Water stress drastically reduces root growth and inulin yield in Cichorium intybus var. sativum independently of photosynthesis. J. Exp. Bot. 2012, 63, 4359-4373. [CrossRef]

31. Wagner, G.R. Content and vacuole/extravacuole distribution of neutral sugars, free amino acids, and anthocyanin in protoplasts. Plant physiol. 1979, 64, 88-93. [CrossRef] [PubMed]

32. Lichtenthaler, H.K. Chlorophylls and carotenoids: Pigments of photosynthetic biomembranes. Methods Enzymol. 1987, 148, 350-382.

33. Zhu, J.K.; Liu, J.; Xiong, L. Genetic analysis of salt tolerance in Arabidopsis: Evidence for a critical role of potassium nutrition. Plant Cell. 1998, 10, 1181-1191. [CrossRef] [PubMed]

34. Läuchli, A.; Grattan, S.R. Plant Growth and Development under Salinity Stress. Advances in Molecular Breeding Toward Drought and Salt Tolerant Crops. Springer: Dordrecht, The Netherland, 2007; pp. 1-32.

35. Negrão, S.; Schmöckel, S.M.; Tester, M. Evaluating physiological responses of plants to salinity stress. Ann. Bot. 2017, 119, 1-11. [CrossRef]

36. Parida, A.K.; Das, A.B. Salt tolerance and salinity effects on plants: A review. Ecotoxicol. Environ. Saf. 2005, 60, 324-349. [CrossRef] [PubMed]

37. Sairam, R.K.; Rao, K.V.; Srivastava, G.C. Differential response of wheat rootstocks to long term salinity stress in relation to oxidative stress, antioxidant activity and osmolyte concentration. Plant Sci. 2002, 163, 1037-1046. [CrossRef]

38. Karimi, S.; Mirfattahi, Z.; Ferguson, L.; Tavallali, V. Using controlled salt stress and $\beta$-aminobutyric acid signaling to decrease transplant failure. Sci. Hortic. 2017, 225, 156-162. [CrossRef]

39. Ben-Romdhane, W.; Ben-Saad, R.; Meynard, D.; Zouari, N.; Mahjoub, A.; Fki, L.; Guiderdoni, E.; Al-Doss, A.; Hassairi, A. Overexpression of AlTMP2 gene from the halophyte grass Aeluropus littoralis in transgenic tobacco enhances tolerance to different abiotic stresses by improving membrane stability and deregulating some stress-related genes. Protoplasma 2018, 255, 1161-1177. [CrossRef] [PubMed]

40. Tufail, A.; Li, H.; Naeem, A.; Li, T.X. Leaf cell membrane stability-based mechanisms of zinc nutrition in mitigating salinity stress in rice. Plant Biol. 2018, 20, 338-345. [CrossRef]

41. Verbruggen, N.; Hermans, C. Proline accumulation in plants: A review. Amino Acids 2008, 35, 753-759. [CrossRef]

42. Hayat, S.; Hayat, Q.; Alyemeni, M.N.; Wani, A.S.; Pichtel, J.; Ahmad, A. Role of proline under changing environments: A review. Plant Signal. Behav. 2012, 7, 1456-1466. [CrossRef]

43. Kamiab, F.; Talaie, A.; Khezri, M.; Javanshah, A. Exogenous application of free polyamines enhance salt tolerance of pistachio (Pistacia vera L.) seedlings. Plant Growth Regul. 2014, 72, 257-268. [CrossRef] 
44. Abbaspour, H.; Afshari, H.; Abdel-Wahhab, M.A. Influence of salt stress on growth, pigments, soluble sugars and ion accumulation in three pistachio cultivars. J. Med. Plant Res. 2012, 6, 2468-2473. [CrossRef]

45. Ashraf, M.H.P.J.C.; Harris, P.J.C. Photosynthesis under stressful environments: An overview. Photosynthetica 2013, 51, 163-190. [CrossRef]

46. Rasool, S.; Ahmad, A.; Siddiqi, T.O.; Ahmad, P. Changes in growth, lipid peroxidation and some key antioxidant enzymes in chickpea rootstocks under salt stress. Acta Physiol. Plant. 2013, 35, 1039-1050. [CrossRef]

47. Abdallah, S.B.; Aung, B.; Amyot, L.; Lalin, I.; Lachâal, M.; Karray-Bouraoui, N.; Hannoufa, A. Salt stress (NaCl) affects plant growth and branch pathways of carotenoid and flavonoid biosyntheses in Solanum nigrum. Acta Physiol. Plant. 2016, $38,72$. [CrossRef]

48. Havaux, M. Carotenoid oxidation products as stress signals in plants. Plant J. 2014, 79, 597-606. [CrossRef]

49. Gould, K.S.; McKelvie, J.; Markham, K.R. Do anthocyanins function as antioxidants in leaves? Imaging of $\mathrm{H}_{2} \mathrm{O}_{2}$ in red and green leaves after mechanical injury. Plant Cell Environ. 2002, 25, 1261-1269. [CrossRef]

50. Jiang, Y.; Deyholos, M.K. Comprehensive transcriptional profiling of NaCl-stressed Arabidopsis roots reveals novel classes of responsive genes. BMC Plant Biol. 2006, 6, 25. [CrossRef]

51. Cassaniti, C.; Leonardi, C.; Flowers, T.J. The effects of sodium chloride on ornamental shrubs. Sci. Hortic. 2009, 122, 586-593 [CrossRef]

52. Olivier, S.; Zhang, W.Q.; Zwiazek, J.J. Tissue sodium and chloride concentrations in relation to needle injury in boreal conifer seedlings subjected to salt stress. Trees 2020, 34, 521-529. [CrossRef]

53. Flowers, T.J.; Munns, R.; Colmer, T.D. Sodium chloride toxicity and the cellular basis of salt tolerance in halophytes. Ann. Bot. 2014, 115, 419-431. [CrossRef]

54. Mahajan, S.; Tuteja, N. Cold, salinity and drought stresses: An overview. Arch. Biochem. Biophys. 2005, 444, 139-158. [CrossRef] [PubMed]

55. Tuteja, N. Mechanisms of high salinity tolerance in plants. Methods Enzymol. 2007, 428, 419-438. [PubMed]

56. Isayenkov, S.V.; Maathuis, F.J. Plant salinity stress: Many unanswered questions remain. Front. Plant Sci. 2019, 10, 80. [CrossRef] [PubMed]

57. Wang, M.; Zheng, Q.; Shen, Q.; Guo, S. The critical role of potassium in plant stress response. Int. J. Mol. Sci. 2013, 14, 7370-7390. [CrossRef] [PubMed]

58. Cakmak, I. The role of potassium in alleviating detrimental effects of abiotic stresses in plants. J. Plant Nutr. Soil Sci. 2005, 168, 521-530. [CrossRef]

59. Wu, H.; Shabala, L.; Shabala, S.; Giraldo, J.P. Hydroxyl radical scavenging by cerium oxide nanoparticles improves Arabidopsis salinity tolerance by enhancing leaf mesophyll potassium retention. Environ. Sci. Nano. 2018, 5, 1567-1583. [CrossRef]

60. Forouzi, A.; Ghasemnezhad, A.; Ghorbani Nasrabad, R. Effects of growth stimulator microbes on growth and ions concentration of stevia under salinity stress conditions. Int. J. Hortic. Sci. Technol. 2019, 6, 217-236.

61. Aboutalebi Jahromi, A.; Hosseini Farahi, M. Seed germination, vegetative growth and concentration of some elements in French marigold (Tageta patula) as influenced by salinity and ammonium nitrate. Int. J. Hortic. Sci. Technol. 2016, 3, $199-209$. 